PRZEGLĄD NAUK HISTORYCZNYCH 2019, R. XVIII, NR 1

http://dx.doi.org/10.18778/1644-857X.18.01.09

DROBNE PRACE I MATERIAEY

C
Member since 2018

JM13714

Matgorzata Karkocha

UNIWERSYTET ŁÓDZKI*

iD https://orcid.org/0000-0002-7747-949X

\title{
Testament szlachetnie urodzonej Anny Jezierskiej z 1745 roku Analiza źródłoznawcza
}

$\mathrm{P}$ rzedmiotem edycji źródłowej jest testament czterdziestokilkuletniej panny Anny Jezierskiej, sporządzony w chorobie, odnaleziony w Archiwum Diecezjalnym w Kielcach, w poszycie Rembieszyce. Zbiór dokumentów dotyczacych parafii i kościoła w Rembieszycach różne 1613-1899 (sygn. IIPR-IV/1). Wprawdzie wyciąg tego aktu $z$ ksiagg grodzkich chęcińskich był już swego czasu publikowany ${ }^{1}$, jednak nie poddano go analizie źródłoznawczej,

* Wydział Filozoficzno-Historyczny, Instytut Historii, Katedra Historii Nowożytnej, e-mail: malgorzata.karkocha@uni.lodz.pl.

${ }^{1}$ „Cui contingit nasci, restat mori”. Wybór testamentów staropolskich z województwa sandomierskiego, oprac. M. Lubczyński, J. Pielas, H. Suchojad, Warszawa 2005, s. [154-156]. Podstawową literaturę dotyczącą testamentów szlacheckich, mieszczańskich i chłopskich $z$ okresu staropolskiego omawiaja: A. Pisanko-B or owik, Testamenty mieszczan grodzieńskich $w$ XVII-XVIII wieku, „Studia Podlaskie" 2005, t. XV, s. 129-133; oraz P. Klint, Edycje testamentów szlacheckich $z$ ksiag grodzkich wielkopolskich $i$ ziemi halickiej z XVII w., „Kwartalnik Historii Kultury Materialnej” 2015, t. LXIII, z. 4, s. 647-648. Ważniejsze prace, które ukazały się w ostatnim czasie: B. Popiołek, Woli mojej ostatniej testament ten... Testamenty staropolskie jako źródło do historii mentalności XVII i XVIII wieku, Kraków 2009; K. Justyniarska-Chojak, Testamenty i inwentarze pośmiertne $z$ ksiag miejskich województwa sandomierskiego (XVI-XVIII wiek), Kielce 2010; „Kościołowi mojemu jako ukochanej oblubienicy mojej”. Wybór testamentów duchownych małopolskich z XVII wieku, wyd. E.E. Wrobel, Kraków 2010; Dług śmiertelności wypłacić potrzeba. Wybór testamentów mieszczan krakowskich z XVII-XVIII wieku, oprac. E. Danowska, Kraków 2011; W. Zielecka-Mikołajczyk, Prawosławni $i$ unici $w$ Rzeczypospolitej XVI-XVIII wieku wobec życia i śmierci $w$ świetle 
a poza tym niektóre informacje wymagaja sprostowania bądź uściślenia ${ }^{2}$. Oprócz tego między obu dokumentami zachodzą istotne różnice. Mianowicie w wydanej drukiem wersji brakuje części wstępnej zawierającej informacje na temat okoliczności sporządzenia aktu, a także formuły końcowej, w której mowa jest o ingrosowaniu go w księgach grodzkich chęcińskich w listopadzie $1747 \mathrm{r}$. Zasadna wydaje się więc ponowna edycja tego źródła, wzbogacona o komentarz krytyczny oraz wiadomości dotyczace samej testatorki i jej najbliższego kręgu rodzinnego.

Wspomniany akt ostatniej woli został spisany 23 grudnia $1745 \mathrm{r}$. w Woli Tesserowej przez susceptanta grodzkiego chęcińskiego Macieja Lewickiego, w obecności świadków: księdza Ludwika Sakiewicza, miejscowego plebana ${ }^{3}$, oraz bliżej nieznanego Antoniego Rogoyskiego, dobrodzieja testatorki. Wszyscy trzej, wskazani w testamencie jako egzekutorzy, podpisali się na nim manu propria. Jezierska, jako osoba niepiśmienna, poświadczyła go potrójnym znakiem krzyża i uwierzytelniła pieczęcia $z$ herbem rodowym ${ }^{4}$.

Oświadczenie woli spisano w języku polskim (jedynie pierwsze i ostatnie wiersze zredagowano po łacinie) na kartkach formatu zbliżonego do A4, zapisanych obustronnie, ponumerowanych od 1 do 6 ,

testamentów, Warszawa 2012; Testamenty szlachty Prus Królewskich z XVII wieku, wyd. J. Kowalkowski, W. Nowosad, Warszawa 2013; U. A u gus ty niak, Testamenty ewangelików reformowanych $w$ Wielkim Księstwie Litewskim $w$ XVIXVIII wieku, Warszawa 2014.

2 Podano błędną nazwę miejscowości, w której spisano oświadczenie woli i daty sprawowania funkcji proboszcza w Rembieszycach przez Ludwika Sakiewicza. Uszczegółowienia wymaga choćby data śmierci testatorki czy informacje o Janie Zabielskim.

3 Józef Ludwik Sakiewicz (Sakowicz, Saksiewicz) - proboszcz kościoła parafialnego pw. Świętych Piotra i Pawła w Rembieszycach w latach 1738-1747. W roku 1751 jako dziedzic Woli Tesserowej wystawił własnym sumptem drewniana świątynię parafialną, która spaliła się w latach dziewięćdziesiątych XVIII stulecia. Por. M. Ka rko cha, Parafia Rembieszyce 1438-2012. Studium z dziejów społeczności lokalnej, Łódź 2013, s. 33, 47; Z. A nu s ik, M. Karko c ha, Z dziejów parafii Rembieszyce w XV-XVIII wieku, [w:] O przeszłości: czasy, miejsca, ludzie. Księga jubileuszowa poświęcona Profesor Jadwidze Muszyńskiej, red. W. Kowalski, Kielce 2016, s. 103, przyp. 50; J. Wiśniewski, Historyczny opis kościołów, miast, zabytków i pamiątek w Jęrzejowskim, Marjówka 1930 (reprint: Kielce 2000), s. 338; [ks. S. Kamiński], Kościół parafialny we wsi Rembieszyce, bez daty, Archiwum Diecezjalne w Kielcach [dalej: ADK], Zbiór dokumentów dotyczących parafii i kościoła w Rembieszycach 1613-1899 [dalej: Zbiór dokumentów], sygn. II PR-IV/1, k. 166v.

${ }^{4} \mathrm{~W}$ polu pieczęci widnieje wyobrażenie herbowe (herb Prus III), a w otoku napis w języku łacińskim. Oba te elementy - graficzny i tekstowy - sa trudne do identyfikacji $z$ powodu niskiej jakości odcisku. 
oznaczonych współcześnie jako karty 52-57. Pismo jest czytelne, ozdobne, cechuje się starannym i regularnym duktem, a w tekście brak skreśleń i poprawek. Prawdopodobnie pisarz sporządził najpierw tzw. brudnopis, notując słowa testatorki na kartce papieru, a dopiero potem w kancelarii grodzkiej ułożył akt według znanej sobie konwencji, co było dość powszechna praktyką ${ }^{5}$.

Postać czyniącej ostatnią wolę Anny Jezierskiej była dotychczas niemal nieznana w literaturze historycznej. Nie ma o niej informacji w Herbarzu polskim Adama Bonieckiego ${ }^{6}$ ani w Herbarzu szlachty polskiej Seweryna Uruskiego ${ }^{7}$. Próżno szukać też na jej temat wiadomości w Tekach Włodzimierza Dworzaczka ${ }^{8}$. Wzmiankowana jest natomiast $\mathrm{w}$ publikacjach dotyczacych parafii Rembieszyce ${ }^{9}$, jak również w Historycznym opisie kościołów ks. Jana Wiśniewskiego ${ }^{10}$. $\mathrm{Z}$ pozostawionego przez zmarła testamentu wynika, że była córka Andrzeja i Heleny $z$ Kossakowskich. Miała siostrę Agnieszkę, która wyszła za chłopa, i brata Józefa, bezpotomnie zmarłego po roku małżeństwa $z$ nieznana $z$ imienia Rudnicką. Anna została wychowana w wierze rzymskokatolickiej i pozostała przy niej do śmierci, dając temu świadectwo na łożu boleści. Choć pochodziła ze stanu szlacheckiego, pozostała niepiśmienna, co w owym czasie nie było niczym nadzwyczajnym wśród przedstawicieli średniej szlachty, do jakiej niewątpliwie zaliczyć należy osiadła w powiecie chęcińskim linię rodu Jezierskich, z której wywodziła się testatorka. Istotna rolę w życiu Anny odegrał niejaki Antoni Rogoyski, nazywany w testamencie dobrodziejem, albowiem „w zdrowiu i w chorobie, w sierostwie" otaczal ja łaskami, zapewniajacc wikt, suknie i wszelkie wygody zarówno w Chęcinach, jak i w Woli Tesserowej, gdzie przebywała pod koniec życia. $Z$ zapisu testamentowego wynika również, że procesowała się $z$ bratem o należny jej dział po matce. Zmarła jako niemłoda już panna, w wieku ponad 40 lat $^{11}$.

${ }^{5}$ Por. Ł. Gołaszewski, Knyszyńskie testamenty składane ustnie wobec władz miejskich na przełomie XVII $i$ XVIII wieku - teksty autorstwa umierajacych, czy też pisarzy miejskich?, „Kwartalnik Historii Kultury Materialnej” 2014, R. LXII, nr 3, s. 350-351.

${ }^{6}$ A. Boniecki, Herbarz Polski, cz. 1 (Wiadomości historyczno-genealogiczne o rodach szlacheckich), t. IX, Warszawa 1906, s. 31-43.

7 S. U r u s ki, Rodzina. Herbarz szlachty polskiej, t. VI, Warszawa 1909, s. 75-85.

${ }^{8}$ Biblioteka Kórnicka PAN, Teki Dworzaczka, edycja elektroniczna, http://teki. bkpan.poznan.pl/index_regesty.html.

${ }_{9}$ M. Karkocha, op. cit., s. 31, 91-92; Z. Anusik, M. Karkocha, op. cit., s. 102.

10 J. Wiśniewski, op. cit., s. 338.

11 Trudno stwierdzić, czy A. Jezierska nie znała dokładnej daty swojego urodzenia, czy też nie chciała jej ujawnić. Faktem jest, że w testamentach staropol- 
Pochowano ją w kościele parafialnym w Rembieszycach, na rzecz którego zapisała połowę swego majątku ${ }^{12}$.

To tyle, a więc niezbyt wiele, co o życiu i koligacjach rodzinnych testatorki można ustalić na podstawie aktu jej ostatniej woli. $Z$ pomoca przychodzą nam jednak źródła kościelne. $Z$ regestu zaślubionych, urodzonych i zmarłych $z$ lat 1677-1810 wynika ${ }^{13}$, że odeszła ona do wieczności 6 stycznia 1746 r., czyli dwa tygodnie po spisaniu oświadczenia woli. $Z$ korespondencji miejscowego proboszcza $z$ władzami kościelnymi dowiadujemy się $z$ kolei, że brat Anny, Jan, piastował urząd sędziego grodzkiego chęcińskiego ${ }^{14}$.

Przechodzac do analizy treści i formalnej struktury edytowanego źródła, należy stwierdzić, że ma ono typowy układ. Ostatnią wolę, sformułowaną w pierwszej osobie („Ja, Anna Jezierska”), otwieraja informacje dotyczace okoliczności sporządzenia aktu (dane urzędnika obecnego podczas dokonywania czynności i osoby testatorki). Właściwy testament rozpoczyna się inwokacja („W imię Trójce Przenajświętszej, Ojca, Syna i Ducha Świętego. Amen”), po której następuja:: prezentacja osoby testatorki, stwierdzenie poczytalności („złożona ciężką choroba, jednak przy zupełnych zmysłach zostając"), refleksja nad przemijalnością życia i niepewnościa godziny śmierci, wyznanie wiary („wyznaję wiarę świętą katolicką rzymska, w której jakom się urodzieła, tak i umierać pragnę"), wreszcie rozbudowana formuła powierzenia duszy miłosierdziu Boskiemu

skich stosunkowo rzadko podawano wiek w latach, ograniczając się zwykle do ogólnikowych stwierdzeń: „będac w starości”, „w podeszłym wieku”, „w lecie podeszłym” itp. Por. B. Popiołek, op. cit., s. 69-71.

12 Nagrobek nie zachował się, gdyż drewniany kościół parafialny został rozebrany, a na jego miejsce w 1751 r. wzniesiono druga świątynię, która spaliła się w latach dziewięćdziesiątych XVIII w. Por. M. Karkocha, op. cit., s. 47; Z. Anusik, M. Karkocha, op. cit., s. 108; J. Wiśniewki, op. cit., s. 334; [ks. S. Kamiński], Kościół parafialny we wsi Rembieszyce, bez daty, ADK, Zbiór dokumentów, sygn. II PR-IV/1, k. 166.

${ }^{13}$ Kopia tego dokumentu, sporządzona w 1853 r. przez dziekana dekanatu kieleckiego, znajduje się w Archiwum Parafialnym w Rembieszycach. Por. też Regest zmarłych od roku 1711, dołaczony do księgi urodzonych, zaślubionych i zmarłych $z$ lat 1677-1778, ADK, sygn. 2, s. 261 ( $\mathrm{nr}$ aktu 1). Dodajmy w tym miejscu, że metryki zmarłych $z$ tego okresu uległy zniszczeniu. Co prawda w ADK znajduje się księga opatrzona nazwa Par. Rembieszyce. Urodzonych, zaślubionych, zmarłych R. 1677-1778 (sygn. 2), jednak próżno szukać w niej akt osób zmarłych.

${ }_{14}$ Przygotowując niegdyś do druku monografię parafii Rembieszyce, natrafiłam na takie informacje w źródłach kościelnych. Obecnie trudno jest mi wskazać konkretny dokument, jako że do wielu $z$ tych źródeł nie mam już dostępu. 
(przez zasługi „niewinnej męki Pana Jezusa” i za przyczyną „Matki Jego Najświętszej Maryi Panny i wszystkich świętych"), a ciała ziemi. Należy zaznaczyć, że testatorka jako miejsce pochówku wskazała kościół parafialny w Rembieszycach, co było przywilejem duchownych, kolatorów, dobroczyńców świątyni i osób szczególnie zasłużonych. W dalszej części aktu zamieszczono dyspozycje majątkowe. Anna Jezierska legowała na dobrach Wola Tesserowa $7 \%$ od 500 złotych polskich wyderkafu, czyli 35 złotych polskich rocznego czynszu $z$ przeznaczeniem na proboszczów rembieskich, w zamian za odprawianie za jej duszę i duszę jej brata Jana jednej mszy świętej w miesiącu. Swemu dobrodziejowi, Antoniemu Rogoyskiemu, zapisała 300 złotych polskich, a Maciejowi Lewickiemu, który przekazał jej informacje dotyczace dóbr macierzystych, „papiery należace do sprawy tej powynajdował w grodzie chęcińskim", sporządził ich wyciagg i nieraz ja "suplementowal wiktem" - 100 złotych polskich. Resztę kapitału (100 złotych polskich) przeznaczyła na zorganizowanie pogrzebu i wydanie obiadu dla księży oraz ubogich ${ }^{15}$. Ponieważ jednak sumy tej „naprędce $z$ dóbr windykować i podnieść od dłużników nie można”, upraszała A. Rogoyskiego, by zapłacił za urządzenie pochówku $z$ własnych funduszy, a potem odebrał sobie należność od dłużników. Wszystkie dobra ruchome (suknie, pieniądze, konie i inne) po zmarłym bracie, które przy jego żonie pozostały, przekazała do windykowania siostrze Agnieszce, „jako po bracie rodzonym przez sukcesją naturalna spadłe". W zakończeniu, obok wskazania egzekutorów ostatniej woli, znalazło się stwierdzenia zachowania prawa do zmiany testamentu w przypadku powrotu do zdrowia oraz informacja o ingrosowaniu go w księgach grodzkich chęcińskich „w czwartek po święcie Wszystkich Świętych" (2 listopada) 1747 r.

$$
* * *
$$

15 Zapisana przez Jezierska suma 100 złotych była, jak na owe czasy, całkiem spora. Analiza większej liczby aktów ostatniej woli wykazała, że zamożniejsi mieszczanie przekazywali na ten cel od 100 do 150 złotych, a przedstawiciele średniozamożnej szlachty 100-600 złotych. Dodać należy, że jedynie nieliczni wymieniali w swych testamentach konkretne kwoty przeznaczone na wyprawienie pogrzebu. Por. A. Pis anko-Borowik, op. cit., s. 150; K. Justyniarska-Chojak, op. cit., s. 233; B. Popiołek, op. cit., s. 94. 
Edytowany dokument opracowano zgodnie $z$ zaleceniami instrukcji wydawniczej Kazimierza Lepszego ${ }^{16}$, $z$ pewnymi jednak modyfikacjami. Stosownie do dominujacej ostatnio w tego typu wydawnictwach tendencji nie dokonano pełnej modernizacji pisowni wyrazów staropolskich, zachowując ich cechy językowe. W związku $z$ tym bez zmian pozostawiono końcówki: -eł, -emi; charakterystyczne staropolskie oboczności językowe: „cieszka” - ciężka, „beł” - był, „sierostwie” - sieroctwie; imiona, nazwiska i nazwy miejscowe (np. Agniszka, Rogoyski, chenciński, Wola Tessarowa). Poprawiono interpunkcję, uzupełniając zdania o przecinki bądź rezygnując $z$ nich w miejscach, gdzie nie było to wymagane. Dwukropek, jako znak kończacy skrót, zamieniono na kropkę. Samogłoski „i”, „y" oraz spółgłoskę „j” oddano zgodnie $z$ aktualnie obowiązującymi zasadami. W przypadku, gdy litera „y” oznaczała dwie głoski, oddano to zgodnie z wymowa, np. "sukcesya” przez "sukcesyja”. Podwojone głoski „ss” i „ff” zastapiono pojedynczymi, np. w słowach „summy”, "wyderkaff”. Uzupełniono pomijane niekiedy litery diakrytyzowane, takie jak „e”, „ć, „n”, „ó, „, „”, „ź, „亡்". Usunięto literę „x”, zastępując ja dwuznakiem „ks” (np. w wyrazach „extrakt”, „xiądz”). Zdarzały się sytuacje, gdzie dwuznak „dź” zamieniano na „ć", jak w słowie „bydź”. Wyraz „exekutor” oddano zgodnie $z$ regułami dzisiejszej pisowni jako „egzekutor”, a słowo „na prędce” zapisano łącznie. Również zgodnie $z$ obecną praktyka użyto wielkich liter. Rozwinięto abrewiacje, zachowując jednak zwroty grzecznościowe: Imć, Imci - Jejmość, Jejmości; W. - Wielmożny. Wyrazy, które odbiegają od współczesnej pisowni, a nie zostały poprawione przez wydawcę, opatrzono skróconym sic w nawiasie kwadratowym [s] dla upewnienia czytelnika o zgodności tekstu wydanego $z$ podstawa. $W$ takich samych nawiasach ujęto początek danej strony w oryginale, rozwiązano skróty, uzupełniono opuszczone przez pisarza litery, jak również podano tłumaczenie na język polski pojedynczych słów i znacznych fragmentów tekstu w języku łacińskim. W źródle występują liczne podkreślenia, wynikające $z$ późniejszej ingerencji w tekst. W celu zredukowania liczby przypisów zrezygnowano $z$ informowania o tym w osobnych odsyłaczach. W przypisach tekstowych zamieszczono uwagi odnoszace się do postaci zewnętrznej i brzmienia tekstu źródłowego oraz lekcje watpliwe. W przypisach rzeczowych objaśniono wymienione w dokumencie osoby i trudniejsze terminy.

${ }^{16}$ Instrukcja wydawnicza dla źródeł historycznych od XVI do połowy XIX wieku, red. K. Lepszy, Wrocław 1953. 


\section{TEKST ŹRÓDEOWY}

Or.: Archiwum Diecezjalne w Kielcach, Zbiór dokumentów dotyczacych parafii i kościoła w Rembieszycach 1613-1899, sygn. II PR-IV/1, k. 52-57.

Wola Tesserowa, 23 grudnia 1745 r.

aAd officium et acta praesentia castrensia capitanealia chencinensia personaliten veniens, nobilis Mathias Lewicki, nomine cujus interest, obtulit eidem officio praesentis, testamentum ultimae voluntatis olim generosa Annae Jezierska virginis adulta, conditum, petens ab officis praesenti, hoc idem testamentum, ad acta sua suscipi et ingrossavi mandavi, quod obtinuit, cujus quidem testamenti tenor est talia ${ }^{a}$ [Do urzędu i akt grodu starostwa chęcińskiego osobiście przybywajac, w swoim interesie, szlachetny Maciej Lewicki przedstawił temu urzędowi testament ostatniej woli niegdyś urodzonej Anny Jezierskiej, panny dojrzałej, prosząc niniejszy urząd, żeby ten testament nakazał do akt swoich wciagnać i ingrosować, co też się stało, którego to testamentu treść jest taka] ${ }^{17}$.

W imię Trójce [s] Przenajświętszej, Ojca, Syna i Ducha Świętego. Amen.

Ja, Anna Jezierska, najniegodniejsza i najmizerniejsza grzesznica, z Rodziców swoich kochanych kato[li]ckich, to jest Ichm[oś]ciów niegdy ś.p. Andrzeja i Heleny Kossowskiej, mał- [k. 52v] żonków Jezierskich, spłodzona, w panieńskim stanie dotychczas i wielkim sierostwie zostająca, majacca lat czterdzieści i kilka przeszło, czując się być śmiertelna, będąc złożona ciężką choroba, jednak przy zupełnych zmysłach zostając, poprzedzając wyroki Boskie niespodziane, taka ostatnia moją wolę niniejszym wyrażam i opisuję testamentem. Naprzód wyznaję wiarę święta katolicką rzymska, w której jakom się urodzieła, tak i umierać pragnę, tak mi Pani Boże dopomóż w Trójcy Świętej Jedyny, za przyczyną Najświętszej Panny Maryi i wszystkich świętych, przy tym moim prawdziwym wiary świętej katolickiej wyznaniu, upadam skruszonym sercem

\footnotetext{
a Fragmentu tego brakuje w opublikowanym w 2005 r. wydawnictwie.

b W oryginale: „cieszka””.

17 Profesorom Zbigniewowi Anusikowi i Janowi Szymczakowi dziękuję za konsultacje podczas tłumaczenia tekstu.
} 
do majesta[tu] miłosierdzia Boskiego i żebrzę pła- [k. 53] czliwie odpuszczenia wszystkich grzechów moich, za które ze wszystkiego serca mego, $z$ całej dusze [s], ze wszystkich sił moich, $z$ całej myśli mojej żałuję, żem Boga mojego, Stworzyciela, Odkupiciela, Oświeciciela nieznośnie grzechami memi obrazieła, więc uciekam się do zasług niewinnej męki Pana Jezusa, do przyczyny Matki Jego, Najświętszej Maryi Panny i wszystkich świętych, których w życiu moim o pomoc i ratunek zwykłam prosić, niechajże w godzinę i punkt śmierci skonania mego przyjda, przybęda mi na ratunek, niech ratują duszę moją i suplikują do Sędziego Sprawiedliwego Boga, aby się $z$ nia miłościwie obyść raczeł, o co cię Boże i ja płaczliwie proszę, nie potępiaj jej. Tak tedy duszę moją grzeszną rozporządziwszy, ciało moje ziemi oddaję, aby w ko- [k. 53v] ściele farnym w Rembieszycach według obrządku kościelnego pochowane było. Substancją zaś moją uboga, która po matce mojej kochanej pozostała (ponieważ ojczystej nie wiem gdzie szukać), tak dysponuję i onę wyrażam. Iż jest sumy kapitalnej dwa tysiace złotych polskich przez niegdy ś.p. W. Imć Pana Jana Zabielskiego, sędziego grodzkiego chęcińskiego ${ }^{18}$, pomienionej matce mojej kochanej na dobrach wsi Rembieszycach w grodzie chencińskim zapisanej, a potym przez sukcesorów ś.p. tegoż Im[ć] Pana Zabielskiego, dzia-

18 Jan Zabielski (Zabilski) (zm. 1718) - syn Jakuba Kazimierza i Zofii z Osiemborów, dziedzic Rembieszyc i okolicznych wiosek (Karsznice, Wola Tesserowa) w latach 1690-1702 (a zapewne także i później), sędzia grodzki i podstarości chęciński w 1716 r. W roku 1691 arcybiskup Michał Stefan Radziejowski (1645-1705) upominał Jana, by pod kara ekskomuniki oddał zaległe dziesięciny proboszczowi rembieskiemu. W tym samym roku Jan Zabielski „za swe grzechy” ofiarował miejscowemu plebanowi „pewne grunty” $z$ obowiązkiem odprawiania mszy świętej do Matki Boskiej (raz w tygodniu przy ołtarzu św. Romualda), a w 1702 r. zapisal 8 morgów ziemi w miejscu zwanym Dęby w zamian za odprawianie dwóch mszy tygodniowo, w tym jednej w sobotę przed ołtarzem Najświętszej Marii Panny, „cujus imago in Eclesia Rembiesyciensis specialiter colitur”. Por. M. Karkocha, op. cit., s. 23, 25 i n.; Z. Anusik, M. Karkocha, op. cit., s. 95, 97, 100; S. Borkiewicz, Z. Linowski, Monografia historyczna i gospodarcza ziemi jędrzejowskiej, Kielce 1937, s. 56, 171, 197; C. Hadamik, D. Kalina, E. Traczyński, Miasto i gmina Małogoszcz [seria: Dzieje i zabytki małych ojczyzn, red. R. Mirowski], Kielce 2006, s. 102, 144, 149; J. Wiśniewski, op. cit., s. 334, 338; M. Rawita-Witanowski, Dawny powiat checciński. $Z$ ilustracjami profesora Jana Olszewskiego, oprac. D. Kalina, Kielce 2001, s. 470, 476; oraz ks. L. Tymowski do Konsystorza Generalnego w Kielcach, Rembieszyce 3 (15) XII 1881, ADK, Akta konsystorskie parafii Rembieszyce 1818-1938, sygn. PR-6/2, k. 260-260v. Z regestu zmarłych wynika, że Jan Zabielski zmarł 15 VI 1718 r. Por. księga urodzonych, zaślubionych i zmarłych $z$ lat 1677-1778, ADK, sygn. 2, s. 258 (nr aktu 1). 
łem między sobą uczynionym, do zapłacenia na siebie przejętej, która to suma dwa tysiące złotych po ś.p. matce mojej kochanej prawem Boskim i sukcesyja naturalna na mnie, na siostrę moja Agniszkę [k. 54] żyjąca i na ś.p. Im[ć] Pana Józefa, brata mego bezpotomnie zeszłego, rodzonych Jezierskich, zarówno spadła, a że potym i pomieniony brat mój kochany, lubo żonę miał i ledwie $z$ nią rok mieszkając bezpotomnie umar[1], tak tedy ta suma pomieniona (o która beł ś.p. brat mój rodzony pomieniony tylko na instancyja swoja do grodu chencińskiego pozwał) na mnie samą i na pomienioną siostrę moję zarówno po tysiącu złotych jednym, na każdej osobę spadać powinna, jakoż i prawem naturalnym, jako na dzieci po matce, spadła. Więc (zostawiwszy tysiąc złotych jeden $z$ sumy kapitalnej dwóch tysięcy dla pomienionej siostry mojej rodzonej żyjącej i za mężem, ale prostym człekiem na [k. 54v] wsi będącej, do windykowania sobie prawem) drugim tysiącem złotych polskich tak rozporzadzam.

Najprzód do kościoła rembieszyckiego, tam gdzie ciało moje leżeć będzie, leguję na wyderkaf Imci Ks[ię]dzu Sakiewiczowi, plebanowi tamecznemu i jego następcom, aby za moję duszę i brata mego Mszy Świętych dwanaście w rok, to jest w każdym miesiącu po jednej Mszy odprawowali, 'pięćset złotych polskich do ${ }^{c}$ windykowania $z$ dóbr Wolid ${ }^{\mathrm{d} 19}$ i podniesienia lub też na tych samych dobrach zapisania, tak aby czynsz roczny po złotych siedem od sta według prawa zapisany beł, przekazuję. $Z$ osobna zaś na pogrzeb i pochowanie ciała mego złotych sto naznaczam. Im[ć] Panu Rogoyskiemu, dobrodziejowi memu, zawdzięcza- [k. 55] jąc jemu łaski i dobrodziejstwa, jak w Chęcinach, tak i tu, Woli Tessarowej, w zdrowiu i w chorobie, i w sierostwie, na sustentacyja mnie wiktem, sprawieniem sukien, czynieniem wszelkich wygów mnie dotąd, sierocie, świadczone, odkazuję i ordynuje złotych polskich trzysta, aby sobie $z$ dóbr od kogo należy windykował. Na ostatek Imci Panu Maciejowi Lewickiemu, susceptantowi ${ }^{20}$ grodzkiemu chencińskiemu, mając wzgląd na szczerość jego, że mi dał informacyją do docho-

c-c Podkreślone.

d Słowo nadpisane nad wierszem.

19 Wola Tesserowa - osada wiejska w dawnym województwie sandomierskim, powiecie chęcińskim (ob. województwo świętokrzyskie, powiat jędrzejowski, gmina Małogoszcz).

20 Susceptant - dawny urzędnik sądowy przyjmujący zeznania. 
dzenia substancyi mojej macierzystej, papiery należące do sprawy tej powynajdował $\mathrm{w}$ grodzie chencińskim, ekstraktami mi wydał i mnie nieraz suplementował wiktem, a potym Imci Panu Rogoyskiemu rekomendował, że mnie dotąd u siebie $[\mathrm{k} .55 \mathrm{v}]$ tenże Imć $z$ łaski swej i miłosierdzia we wszystkich potrzebach moich prowiduje, leguję i przekazuję złotych sto polskich, aby sobie $z$ dóbr, od kogo należyć będzie, windykował i odebrał. A żem sto złotych na pogrzeb ciała mego naznaczeła, a tych pogotowiu naprędce $z$ dóbr windykować i podnieść od dłużników nie można, zaczym obliguję i upraszam Imć Pana Rogoyskiego dobrodzieja, ażeby w rekompensę pomienionych trzechset złotych, com Jegomości niniejszym legowała testamentem, dał i założeł swoich pieniędzy złotych sto, to jest na sprawienie pogrzebu, obiadu dla Ichm[oś]ciów Księży i ubogich. ${ }^{\mathrm{d} P o n i e w a z ̇ ~ z a s ́ ~ r z e c z y ~ r u c h o m e ~ r o ́ z ̇ n e, ~ j a k o ~ t o ~}{ }^{\mathrm{e}}$ suknie, pieniądze, konie i insze [k. 56] porządki po nieboszczyku bracie moim, przy żonie, to jest Imć Paniej z domu Rudnickiej, pozostały, przeto oneż siostrze mojej do windykowania przekazuję, jako po bracie rodzonym przez sukcesyja naturalna spadłe. Za opiekunów zaś i egzekutorów tego mego testamentu ostatniej woli Imci Ks. Sakiewicza, plebana rembieszyckiego, Imci Pana Antoniego Rogoyskiego i Imć Pana Macieja Lewickiego obieram i uniżenie upraszam, aby tej woli mojej zadosyć we wszystkim uczynieli, a in quantum [o ile] Pan Bóg przyprowadziełby mnie do pierwszego zdrowia, tedy sobie moc zupełna tego testamentu skasowania, poprawienia rezerwuję. Który to mój testa- [k. 56v] ment takiej wagi mieć chcę, jakoby aktami grodzkiemi któremikolwiek przeze mnie roborowany beł, na co się nie umiejąca pisać, dla lepszej wiary, znakami Krzyża Świętego podpisuję.

Działo się w Woli Tessarowy, dnia dwudziestego trzeciego grudnia roku tysiąc sied[e]mset czterdziestego piątego. Ja, Anna Jezierska, nieumiejaca pisać, znaki Krzyża Świętego kładę +++.

Ks. Ludwik Sakiewicz, pleban rembieszycki, jako praesens [obecny] będący przy tym testamencie i egzekutor podpisuje się manu propria [własnoręcznie]. Antoni Rogoyski jako przy tym będący egzekutor podpisuje się. Maciej Lewicki jako będący przy testamencie tym praesens i [k. 57] do napisania jego proszony egzekutor podpisuje się manu propria. ${ }^{\mathrm{f} O r g i n a l e ~ v e r o ~ i p s u m, ~ p r a-~}$ efati testamenti idem nobilis offerens cirea acta praesentia reliquit

\footnotetext{
e Podkreślone.
} 
[Po odczytaniu tego testamentu, tenże szlachetny opuszcza urząd, otrzymując to, o co prosił].

${ }^{\mathrm{g}}$ Actum in castro chencinensi, feria quarta, post festum omnium sanctorum, proxima anno domini millesimo septingentesimo quadragesimo septimo ${ }^{\mathrm{fg}}$ [Działo się w grodzie chęcińskim, w czwartek po święcie Wszystkich Świętych, Roku Pańskiego tysiąc siedemset czterdziestego siódmego].

Correxit [korekta] Laskowski m[anu] p[ro]pria

Legit [odczytał] Szwedowski
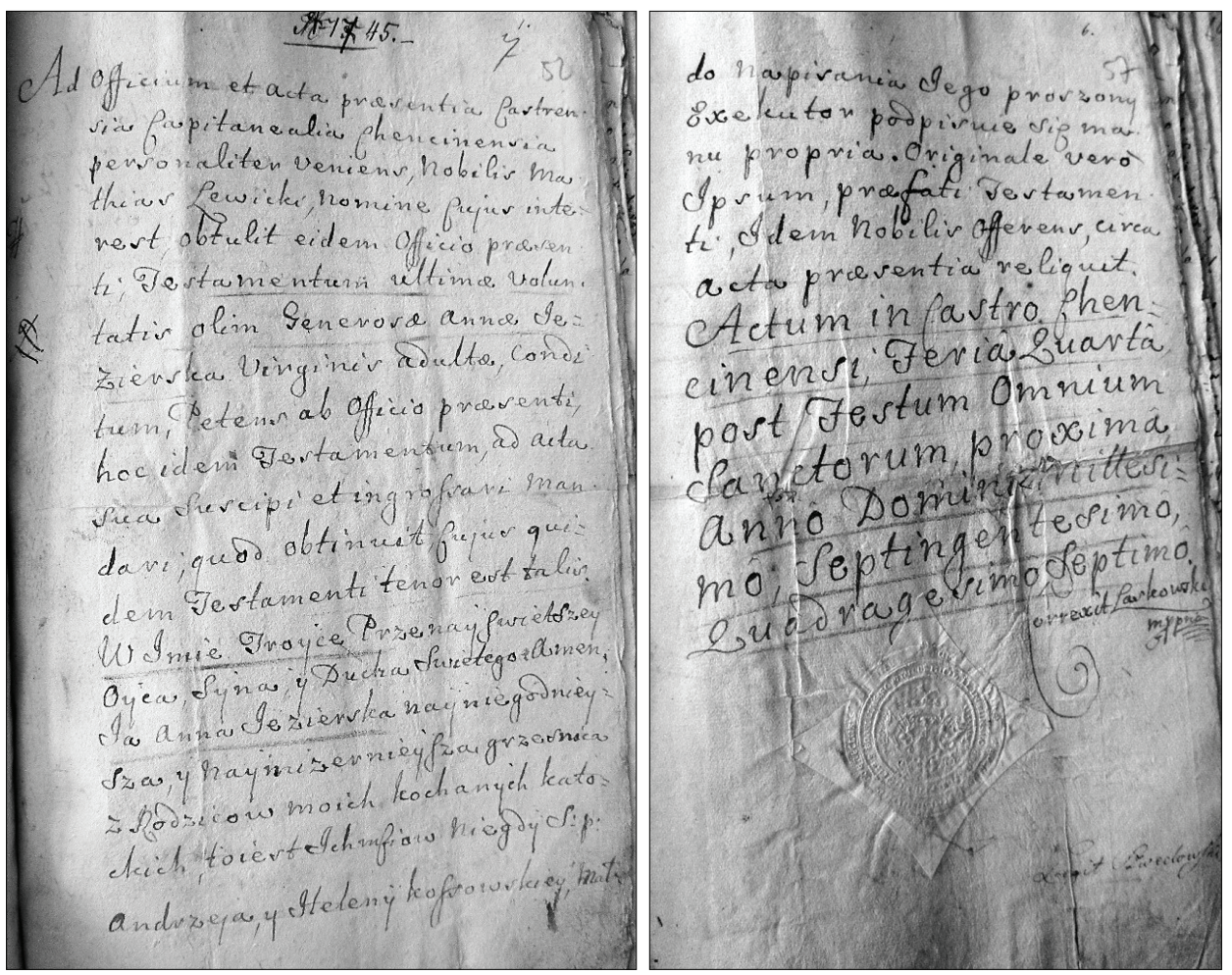

Pierwsza i ostatnia karta testamentu Anny Jezierskiej, fot. M. Karkocha

f-f Fragmentu tego brakuje w opublikowanym już źródle.

g-g Większa czcionka. 


\section{Bibliografia}

\section{Ź́ródea ARChiwalne}

Archiwum Diecezjalne w Kielcach [ADK]

Akta konsystorskie parafii Rembieszyce 1818-1938, sygn. PR-6/2.

Księga urodzonych, zaślubionych i zmarłych $z$ lat 1677-1778, sygn. 2.

Zbiór dokumentów dotyczacych parafii i kościoła w Rembieszycach 1613-1899, sygn. II PR-IV/1, k. 166v.

Biblioteka Kórnicka PAN

Teki Dworzaczka.

\section{OPRACOWANia}

"Cui contingit nasci, restat mor". Wybór testamentów staropolskich z województwa sandomierskiego, oprac. M. Lubczyński, J. Pielas, H. Suchojad, Warszawa 2005.

„Kościołowi mojemu jako ukochanej oblubienicy mojej”. Wybór testamentów duchownych małopolskich z XVII wieku, wyd. E.E. Wrobel, Kraków 2010.

Anusik Z., Karkocha M., Z dziejów parafii Rembieszyce w XV-XVIII wieku, [w:] O przeszłości: czasy, miejsca, ludzie. Księga jubileuszowa poświęcona Profesor Jadwidze Muszyńskiej, red. W. Kowalski, Kielce 2016, s. 93-109.

Boniecki A., Herbarz Polski, cz. 1 (Wiadomości historyczno-genealogiczne o rodach szlacheckich), t. IX, Warszawa 1906.

Borkiewicz S., Linowski Z., Monografia historyczna i gospodarcza ziemi jędrzejowskiej, Kielce 1937.

Dług śmiertelności wypłacić potrzeba. Wybór testamentów mieszczan krakowskich z XVII-XVIII wieku, oprac. E. Danowska, Kraków 2011.

Gołaszewski Ł., Knyszyńskie testamenty składane ustnie wobec władz miejskich na przełomie XVII i XVIII wieku - teksty autorstwa umierajacych, czy tez pisarzy miejskich?, „Kwartalnik Historii Kultury Materialnej” 2014, R. LXII, nr 3, s. 345-366.

Hadamik C., Kalina D., Traczyński E., Miasto i gmina Małogoszcz [seria: Dzieje i zabytki małych ojczyzn, red. R. Mirowski], Kielce 2006, s. 102, 144, 149.

Instrukcja wydawnicza dla źródeł historycznych od XVI do połowy XIX wieku, red. K. Lepszy, Wrocław 1953.

Justyniarska-Chojak K., Testamenty i inwentarze pośmiertne $z$ ksiag miejskich województwa sandomierskiego (XVI-XVIII wiek), Kielce 2010.

Karkocha M., Parafia Rembieszyce 1438-2012. Studium z dziejów społeczności lokalnej, Łódź 2013.

Klint P., Edycje testamentów szlacheckich z ksiag grodzkich wielkopolskich $i$ ziemi halickiej z XVII w., „Kwartalnik Historii Kultury Materialnej” 2015, t. LXIII, z. 4, s. 647-660.

Pisanko-Borowik A., Testamenty mieszczan grodzieńskich $w$ XVII-XVIII wieku, „Studia Podlaskie” 2005, t. XV, s. 129-185. 
Popiołek B., Woli mojej ostatniej testament ten... Testamenty staropolskie jako źródło do historii mentalności XVII i XVIII wieku, Kraków 2009.

Rawita-Witanowski M., Dawny powiat chęcinski. Z ilustracjami profesora Jana Olszewskiego, oprac. D. Kalina, Kielce 2001.

Testamenty szlachty Prus Królewskich z XVII wieku, wyd. J. Kowalkowski, W. Nowosad, Warszawa 2013. U. Augustyniak, Testamenty ewangelików reformowanych w Wielkim Księstwie Litewskim w XVI-XVIII wieku, Warszawa 2014.

Uruski S., Rodzina. Herbarz szlachty polskiej, t. VI, Warszawa 1909.

Wiśniewski J., Historyczny opis kościołów, miast, zabytków i pamiątek $w$ Jędrzejowskim, Marjówka 1930 (reprint: Kielce 2000).

Zielecka-Mikołajczyk W., Prawosławni i unici w Rzeczypospolitej XVI-XVIII wieku wobec życia $i$ śmierci $w$ świetle testamentów, Warszawa 2012. 